Marina Stamenović ${ }^{1}$, Danijela Kovačević ${ }^{1}$ Vesna Alivojvodić ${ }^{1}$, Slaviša Putić ${ }^{2 *}$

${ }^{1}$ Belgrade Polytechnic, Vocational college in Belgrade, Belgrade, Serbia, ${ }^{2}$ University of Belgrade, Faculty of Technology and Metallurgy, Belgrade, Serbia
Review paper ISSN 0351-9465, E-ISSN 2466-2585 UDC: $620.97:[620.282+66.065 .32]$ doi:10.5937/zasmat2001013S

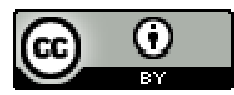

Zastita Materijala 61 (1) $13-18$ (2020)

\title{
Thermal treatment of composite wastes for energy recovery
}

\begin{abstract}
The expression waste-to-energy technologies is increasingly being used regarding waste reduction and utilization. Waste-to-energy technologies are procedures used to generate different forms of energy starting from a waste source. Considering that this paper is focused on composite waste, the previously mentioned procedures can be divided into mechanical, thermal and chemical treatment of composite waste. Thermal treatment processes provide a wide range of options to produce electricity, heat, oils, gases, fuels and chemicals starting from composite waste. Some procedures are used for commercial purposes, while many are still being developed in laboratories or semi-industrial plants. The presented paper is focused to briefly review recent research in the field of thermal treatment of composite waste materials.
\end{abstract}

Keywords: composite waste, recycling, thermal treatment, fibres, energy.

\section{INTRODUCTION}

The two main factors: rapid population growth and constant increasing rate of urbanization contributed to the increased consumption of energy and natural resources in the world. Considering that fact, the energy potential by 2050 is expected to be enlarged three times compared to the existing resources. The development of new technologies, expansion of energy efficiency programs and the use of renewable energy sources has been reported though numerous studies and continues to be an area of interest of scientific and professional communities. The development of renewable energy sources (solar, hydropower, wind energy, biomass) has been proven to be a potential solution in the further. The waste presents one of the most important renewable energy sources and energy can be obtained through the use of waste in order to generate heat and electricity.

${ }^{*}$ Corresponding author Slaviša Putić

Email: slavisa@tmf.bg.ac.rs

Paper received: 05. 09. 2019.

Paper corrected: 23. 10. 2019.

Paper accepted: 03. 11. 2019.

Paper is available on the website: www.idk.org.rs/journal
Higher performance of composite materials in terms of improved mechanical, termal and environmental properties, its relatively low mass as well as corrosion resistance, led to the replacement of large number of traditional materials with composites. The automotive, aviation and aerospace industry, shipbuilding and process industry are just some of the fields where this replacement took place. Composite materials of different types are used, including those with polymeric, metal or ceramic matrix. Reinforcement of these materials, depending on the purpose, can be fillers such as particles or fibres. The second approach is production of structural composites (laminates). The most common is the use of composite materials with polymer matrix, thermostable or thermoplastic. Although these materials are used in products with a long lifetime, the optimal solution for handling waste composite materials must be found, otherwise it will be generated in large quantities.

Disposal of the composite materials would be the simplest solution, but not environmentally friendly. The decomposition of this type of waste material, at the landfill would be very slow, and considering growing volumes of composite wastes, it would require more landfill space. In general, only dumpsite materials that have no usable value should be disposed at the landfill. 
Optimal recycling method for composite materials has not been sufficiently developed mostly due to the heterogeneity of their structure. The recycling process of the composite materials is extremely complex. Methods of recycling and utilization (Figure 1) of composite waste materials are technologically and economically limited. Thermal treatment is used as an alternative to the traditional combustion processes, which contributes to the reduction of the amount of this type of waste deposited at the landfill, and therefore to the preservation of the environment. Thermal treatment methods with energy generation are successfully implemented in Europe, Japan and North America.

This paper provides an overview of composite waste thermal treatment methods during which energy production takes place and also emphasizes the importance of this process.

\section{METHODS FOR REUSE OF COMPOSITE WASTE MATERIALS}

Composite waste materials [1] can be treated in a several different ways: recycled in order to get materials having the same properties as the primary materials; recycling products resulted in even poorer properties than primary materials; recycled by using chemical methods (converted into energy).
The mechanical recycling procedure has been the most commonly used process. This procedure includes grinding operations of composite materials, followed by separation into two components, first component with higher fiber content and a second component with higher matrix content. The mechanical recycling process of composites requires large energy consumption, and all inherent properties of the recycled products were reduced [2].

Thermal recycling process (pyrolysis or thermal methods in a fluidization column) aims to carry out separation and recycling of the only one composite component. Burning of composite materials is still considered as a one of the most effective methods for recycling this type of materials. The efficiency of this method, on the other hand, depends on the composition of the composite and the thermal power of its components. Chemical recycling methods for composites have not yet been sufficiently developed. Using these methods, the matrix can be depolymerized and reinforcement extracted for further recycling, or chemical matrix removed in order to extract expensive composite components (fillers such as carbon fibers, glass fibers...). A general problem with chemical recycling is high amount of hazardous waste generation.

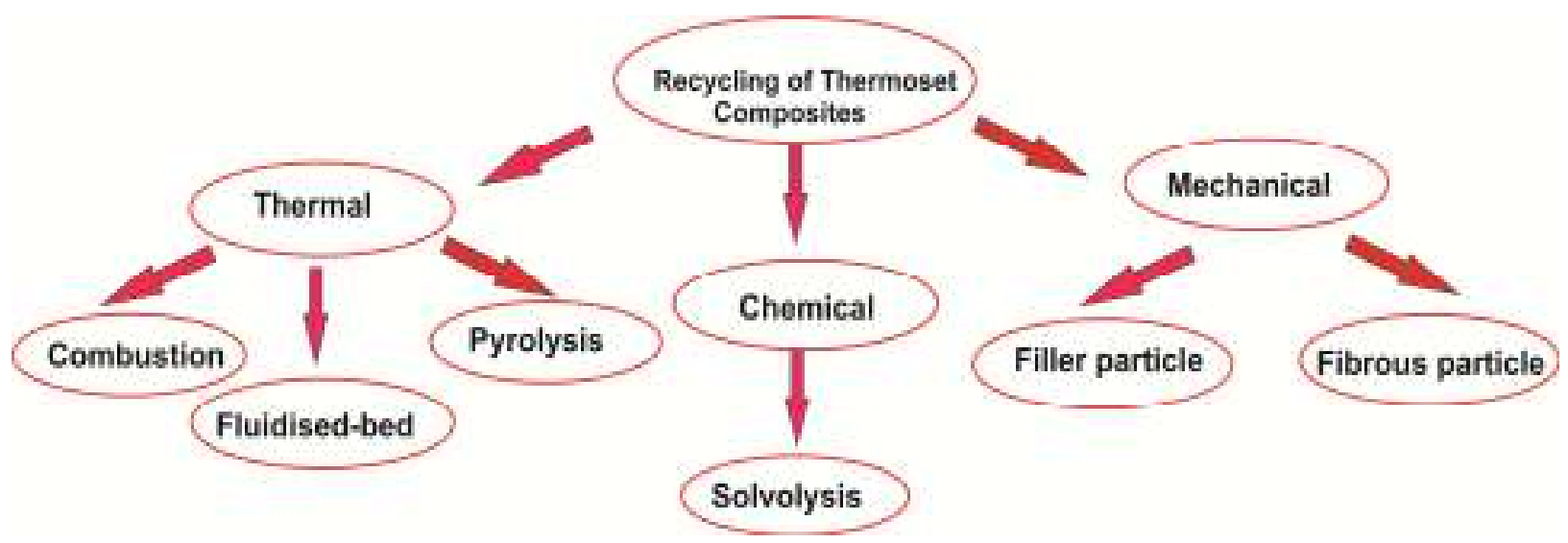

Figure 1. Recycling of thermoset composites [3]

Slika 1. Metode reciklaže kompozitnih materijala [3]

\section{THERMAL WASTE TREATMENT}

\section{Combustion}

Combustion/burning/incineration is commonly and widely used thermal treatment in order to produce energy in the form of electricity and/or heat from composite waste materials. The process is based on the fact that the composite material is burned in a furnace [4]. It can be applied to all types of composite waste consisted from hydrocarbons. However, release of $\mathrm{CO}_{2}$ and toxic emissions have been the main reason why this process is considered undesirable and many efforts have been made to explore alternative 
approaches. The environmental issue in combustion recycling process is the main disadvantages, which can be partially overcome in the case when polymer is reinforced by natural fibers. Incineration of composite natural fiber reinforced does not generates hazardous residues [5].

Fraisse et co-workers [6] investigated production of the new composite materials filled with recycled glass fibers. The glass fiber have been previously obtained by using burning recycling method. They found that some mechanical properties (maximum stress of the composite) have been reduced by $90 \%$ when recycled fibres were used as a reinforcement. The glass fibre sensitivity and difficulties in handling them greatly complicate the production process of the new composite materials. The same group of authors noticed a lower fiber volume fraction in the new composite with recycled glass fibers, which is quite expected result considering that arrangement of recycled fibers is not so good as pristine ones [6].

\section{Pyrolysis}

Pyrolysis has shown to be a widely used process for treatment of composite waste in order to get individual components (gas, oil, fibers...), introduced as an alternative method to conventional combustion recycling process. The treatment itself is based on the heating of waste composite material in the absence of air. Optimal temperature regime at which pyrolysis is carried out has to be adjusted according to the type of matrix and fillers, to prevent its degradation at extreme high temperatures. Fibers and oils obtained by the pyrolysis process can be further processed and used for the production of new composites, energy production or for other purposes [5]. The yield and composition of the pyrolysis products are closely related to the type of composite material and process conditions. Pyrolysis of composites with polymer matrix results in shortening of polymer chains and production of the species with lower molecular weights (oils, hydrocarbon gases, hydrogen, char) [7]. The product recovered (oils, gases) showed a high calorific value, which is also one of the advantages of pyrolysis. The char obtained during the pyrolysis process may be used instead of carbon black [4]. The speed of the process itself (as one of parameters of the reaction conditions) can also greatly affect the final products. According to speed, we can distinguish three types of pyrolysis: slow, fast and flash. It should also be emphasized that there is no clear boundary between these three types of pyrolysis [7].

A partial pyrolysis has been one of the approaches to thermal waste treatment. This process involves combustion of composite material in a limited supply of oxygen. Mechanical properties of the fibres obtained on this manner are almost unchanged compared to the pristine ones [8]. On the other hand, the application of the pyrolysis process in order to obtain glass fiber fillers resulted in a material with significantly disrupted mechanical properties [9].

Pyrolysis heat treatment has proved to be a better solution for recovery of carbon fiber then glass fibers particularly regarding reduction in mechanical properties. However, the surface of a carbon fiber recovered by the pyrolysis is partly covered with a char and usually additional treatment to remove the char is required. Glass fibers obtained on this manner from composite waste showed much greater damage and solution for this problem would be subsequent posttreatment. The post-treatment to recover glass fibre properties after thermal treatment has been proposed by University of Strathclyde [10]. Posttreatment is based on application of hot sodium hydroxide and properties of post treated glass fiber can be competitive to pristine.

A catalytic pyrolysis for recycling carbon fibres from composite waste has also been reported [6, 11]. This process takes place at very low temperatures (at around $200^{\circ} \mathrm{C}$ ) with the addition of a catalyst. The tensile strength of recycled fibres is slightly different from the tensile strength of pristine ones (from 1 to 17\%). A belt pyrolysis to recovery carbon fibres has been developed and commercialized [12]. The process takes place in two reactors and the first step is matrix decomposition during which the temperature is strictly controlled. In the second reactor a stream of air consisting of fumes from the first reactor is mixed with oxygen to remove the char from the surface of carbon fibres [12]. The main disadvantage of belt pyrolysis is the thickness of the composite and the composition of the matrix [13].

\section{Microwave assisted pyrolysis}

Another type of thermal treatment of composite waste is a microwave assisted pyrolysis. This is a relatively new treatment, developed by Tech-En Ltd. in Hainault, UK $[14,15]$. The method is based on heating the core of material in which thermal transfer takes place extremely quickly [16]. It is 
confirmed that the products of microwave assisted pyrolysis demonstrated a higher calorific value than amount of electrical energy consumed during the recycling process, which is another benefit of this recycling method [4]. Microwave assisted pyrolysis could be a good recycling solution for composite waste having carbon fibre filling considering that carbon materials are good microwave-absorbents and they have capacity to absorb and convert microwave energy into heat [4]. This type of pyrolysis is not applicable to a great extent; it is still being developed under laboratory conditions. A microwave assisted pyrolysis has proven to be a method that has potentials, but requires a time for development and commercialization in the future [16].

\section{Fluidized bed recycling process}

A fluidized bed recycling process is shown to be an effective method for thermal processing of composite wastes, especially when it comes to unsorted ones and contaminated composite materials. This method implies use of fluidized silica send in a preheated air $\left(450-550^{\circ} \mathrm{C}\right)$. Composite scarps are size reduced and added to a sand bed prior to fluidization. The process itself provides evaporation of the polymer and separation of the filler particles which are contained in a steam of preheated air. Fillers are lather separated from the gas in a cyclone. Both, carbon and glass fibers recycled in a fluidized bed recycling process are partially weakened in terms of their mechanical properties. Reduction of tensile straight is more pronounced in the recycled glass fibers and it is also found that the higher temperature of the preheated air less contributes to disruption of mechanical properties of carbon fibers $[1,8,17]$. The operating temperature mast be selected to ensure the matrix decomposition but to avoid it but to avoid as much as possible fibers degradation.

A fluidized bed recycling process provides reusability of both polymer matrix and fillers (fibers, particles) as well. The evaporated organic components can be further processed (burned) in order to get heat and energy, while fillers can be reused in a production of new composite materials [1]. Studies have shown that the use of recycled carbon fiber in a production of new composite material can reduce costs up to $70 \%$.

The process itself and first laboratory facility for a fluidised bed process for the recovery of carbon fibres has been developed at the University of Nottingham, but many efforts have been made to scale up to a pilot plant and use it in commercial purposes [18]. By optimizing process parameters of proposed commercial plant, authors concluded that total energy input required to recover the carbon fibre is typically $5-10 \%$ of that needed to produce virgin ones [18].

The application of carbon fibres recovered by fuidized bed recycling process is mainly related to structural reinforcement of polymer composite. The amount of fillers and fibre volume fractions determines properties of the new manufactured composites. Among other things, those parameters also dictate mechanical properties such as strength and stiffness and those properties can be improved by improving arrangement (i.e. density of packing) of fibres inside polymer matrix. The glass fibres recovered by fuidized bed recycling process are used as a substitute for pristine glass fibers or for the manufacture of glass fibre veil [19].

Considering that production of composite materials is rapidly increased due to their advantages over conventional materials (i.e. control of the targeted properties), the problem of efficient recycling is a burning issue. However, only a small amount of composite materials is recycled. The reasons for this, among other things, are difficulties of the process itself, difficulties in establishing an efficient recycling system, the lack of legal regulation. Choosing the best recycling method for waste composite materials is a very complex issue. The selection of the optimal method depends on the multi-criteria analysis. Three main factors included in such an analysis are economical, ecological and social [20]. Group of authors [20] showed eight sustainability performance criteria chosen for carrying out multicriteria decision making analysis (MCDA) to compare four alternative polymer matrix composite waste recycling methods. From this last study [21], it can be seen the complexity of choosing an optimal recycling method for a particular composite material of interest.

\section{CONCLUSION}

In this paper, the recycling procedures of composite waste materials have been presented. The focus was primarily on waste thermal treatment, significance and application of different thermal treatment methods. The presented thermal treatments are combustion/burning/incinerations, pyrolysis, microwave assisted pyrolysis and fluidized bed recycling. The advantages and disadvantages of combustion process of composite waste have been highlighted. Also, variations of 
different pyrolysis methods (conventional in the absence of air, partial pyrolysis with limited amount of air, catalytic pyrolysis and microwave assisted pyrolysis) have been discussed. A fluidized bed recycling process has shown to be promising thermal treatment, especially for the mixed composite waste. Regarding filler components of the composite waste, the greatest attention was focused on recovery of carbon fibres and glass fibres as highly valuable fillers. The importance of reuse all composite waste constituents, matrix, fillers or products obtain from its decomposition in order to obtain energy has also been emphasized.

\section{REFERENCES}

[1] Y.Liu, M.Farnsworth, A.Tiwari (2017) A review of optimization techniques used in the composite recycling area: State-of-the-art and steps towards a research agenda Journal of Cleaner Production, 140(3), 1775-1781.

[2] Y.Yang, R.Boom, B.Irion, D.J. van Heerden, P. Kuiper, H. de Wit, (2012) Recycling of composite materials, Chemical Engineering and Processing, 51, 53-68.

[3] S.J.Pickering (2006) Recycling technologies for thermoset composite materials-current status Composites: Part A, 37 (8), 1206-1215.

[4] S.Shiung Lam, H.A.Chase (2006) A Review on Waste to Energy Processes Using Microwave Pyrolysis, book Thermochemical Waste Treatment Combustion, Gasification, and Other Methodologies edited by Elena Cristina Rada, Apple Academic Press, Inc., p. 221-258.

[5] S.Halliwell End of life option for composite waste: recycle, reuse or dispose? (2006) National composite network best practice guide, NetComposites 2006. Error! Hyperlink reference not valid.

[6] A. Fraisse, J. Beauson, P. Brøndsted, B. Madsen (2016) Thermal recycling and re-manufacturing of glass fibre thermosetting composites, 7th Ris $\varnothing$ International Symposium on Materials Science IOP Conference Series: Materials Science and Engineering, Volume 139, doi:10.1088/1757899X/139/1/012020.

[7] P.Jayarama (2016) Energy Recovery from Municipal Solid Waste by Thermal Conversion Technologies, CRC Press Taylor \& Francis group, London UK

[8] S.Job (2010) Composite recycling - KTN Report, Summary of the recent research and development https://compositesuk.co.uk/system/files/documents/ Recycling\%20Report\%202016.pdf

[9] A.M.Cunliffe, N.Jones P.T.Williams (2003) Pyrolysis of composite plastic waste, Environmental Technology, 24 (5), 653-663.
[10] J. L.Thomason, U.Nagel, L.Yang, E.Sáez (2016) Regenerating the strength of thermally recycled glass fibres using hot sodium hydroxide Composites Part A: Applied Science and Manufacturing, 87, 220-227.

[11] J.-M.Gosau, T.F.Wesley, R.E.Allred (2009) Carbon fiber reclamation from state-of-the-art 2 nd generation aircraft composites, International SAMPE Symposium and Exhibition (Proceedings) Vol. 54 https://www.researchgate.net/publication/ 286718518 Carbon fiber reclamation from stateof-the-art_2nd_generation_aircraft_composites

[12] J.Davidson, R.Price (2009) European Patent Application, 19 January 2009. Process WO/2009/090264

[13] S.Melendi-Espina, C.Morris, T.Turner, S.Pickering (2016) Recycling of carbon fibre composites, Carbon 2016, At Penn State University, State College, United States, https://www. researchgate.net/publication/304571651_Recycling _of_carbon_fibre_composites

[14] K.M.Holland (1995) Apparatus for Waste Pyrolysis. U.S. Patent $5,387,321$

[15] K.M.Holland (1994) Process of Destructive Distillation of Organic Material. U.S. Patent 5,330, 623.

[16] S.Job, G.Leeke, P.Tarisai Mativenga, G.Oliveux, S. Pickering, N.Aizat Shuaib (2016) Composites recycling// Where are we now? Composites UK Ltd https://compositesuk.co.uk/system/files/documents/ Recycling\%20Report\%202016.pdf

[17] S.J.Pickering, R.M.Kelly, J.R.Kennerley, C.D. Rudd, N.J.Fenwick (2000) A fluidized bed process for the recovery of glass fibres from scrap thermoset composites. Composites Science and Technology, 260 (4), 509-523.

[18] S.J.Pickering, T.A.Turner, F.Meng, C.N.Morris, J.P. Heil, K.H.Wong, S.Melendi (2015) Dvelopments in the fluidised bed process for fibre recovery from thermoset composites, 2nd Annual Composites and Advanced Materials Expo, CAMX 2015, At Dallas, TEXAS USA Error! Hyperlink reference not valid.

[19] S.J.Pickering (2010) Thermal methods for recycling waste composites in edited by Vannessa Goodship, book Management, recycling and reuse of waste composites, UK Woodhead Publishing Limited and CRC Press LLC pp. 65-100.

[20] M.H.Saad, M.A.Nazzal, B.M.Darras (2019) A general framework for sustainability assessment of manufacturing processes. Ecological Indicators, 97, 211-224.

[21] I.Delvere, M.Iltina, M.Shanbayev, A.Abildayeva, S. Kuzhamberdieva, D.Blumberga (2019) Evaluation of Polymer Matrix Composite Waste Recycling Methods, Environmental and Climate Technologies, 23 (1), 168-187. 


\section{IZVOD}

\section{TERMIČKI TRETMAN OTPADNIH KOMPOZITNIH MATERIJALA U CILJU DOBIJANJA ENERGIJE}

Proizvodnja energije iz otpadnih materijala primenom različitih tehnologija je jedan od načina ponovne upotrebe $i$ ujedno redukcije otpadnih materijala. Sve ove tehnologije reciklaže imaju jednu zajedničku karakteristiku - dobijanje energije u različitim oblicima, polazeci od otpadnih materijala kao sirovina. Imajuci u vidu da je ovaj rad fokusiran na kompozitne otpadne materijale, pomenute procedure se mogu podeliti na mehaničke, termičke $i$ hemijske tretmane kompozithog otpada. Termički tretmanima kompozitnog otpada je moguća proizvodnja energije u vidu eliktriciteta, toplote, ulja, gasova, goriva i različitih hemijskih jedinjenja. Pojedine procedure su uvedene u komercijalnu upotrebu, dok se veliki broj njih trenutno razvija u laboratorijskim ili poluindustrijskim postrojenjima. $U$ radu je ukratko dat prikaz trenutnog stanja i inovacija u oblasti termičkog tretmana otpadnih kompozitnih materijala.

Ključne reči: otpadni kompoziti, recikliranje, termički tretman, vlakna, energija

\section{Pregledni rad}

Rad primljen: 05. 09. 2019.

Rad korigovan: 23. 10. 2019.

Rad prihvaćen: 03. 11. 2019.

Rad je dostupan na sajtu: www.idk.org.rs/casopis

(C) 2020 Authors. Published by Engineering Society for Corrosion. This article is an open access article distributed under the terms and conditions of the Creative Commons Attribution 4.0 International license (https://creativecommons.org/licenses/by/4.0/) 